\title{
Testing and Performance of the Pacific Northwest Laboratory 6-kg Retort
}
K. B. Olsen
J. C. Evans
D. C. Girvin
D. S. Sklarew
C. L. Nelson

February 1984

Prepared for the U.S. Department of Energy under Contract DE-AC06-76RLO 1830

Pacific Northwest Laboratory Operated for the U.S. Department of Energy by Battelle Memorial Institute 


\section{DISCLAIMER}

This report was prepared as an account of work sponsored by an agency of the United States Government. Neither the United States Government nor any agency thereof, nor any of their employees, makes any warranty, express or implied, or assumes any legal liability or responsibility for the accuracy, completeness, or usefulness of any information, apparatus, product, or process disclosed, or represents that its use would not infringe privately owned rights. Reference herein to any specific commercial product, process, or service by trade name, trademark, manufacturer, or otherwise, does not necessarily constitute or imply its endorsement, recommendation, or favoring by the United States Government or any agency thereof. The views and opinions of authors expressed herein do not necessarily state or reflect those of the United States Government or any agency thereof.

PACIFIC NORTHWEST LABORATORY operated by

BATTELLE

for the

UNITED STATES DEPARTMENT OF ENERGY under Contract DE-AC06-76RLO 1830

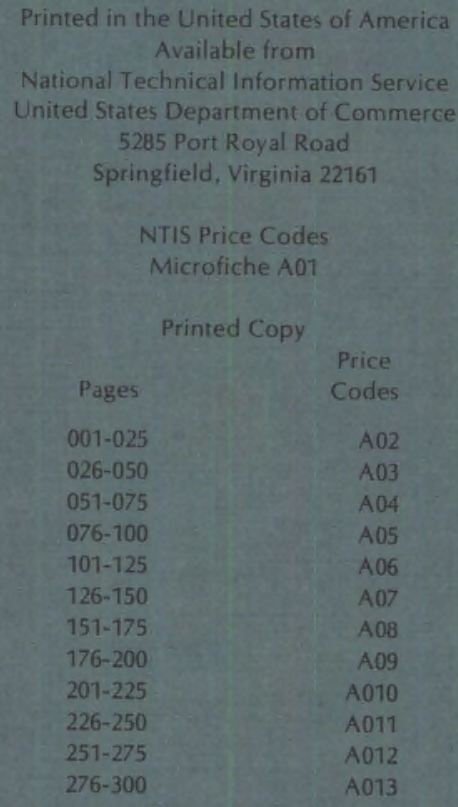


TESTING AND PERFORMANCE OF THE PACIFIC NORTHWEST LABORATORY 6-kg RETORT
K. B. 01 sen
J. C. Evans
D. C. Girvin
D. S. Sklarew
C. L. Nelson

February 1984

Prepared for the U.S. Department of Energy under Contract DE-AC06-76RLO 1830

Pacific Northwest Laboratory

Richland, Washington 99352 



\section{ACKNOWLEDGMENTS}

This program is funded by the U.S. Department of Energy, Office of Fossil Energy, under Contract DE-ACO6-76RLO 1830. 



\section{$\underline{\text { ABSTRACT }}$}

This report describes and discusses the design, construction, calibration and operations of the Pacific Northwest Laboratory (PNL) $6-\mathrm{kg}$ retort. Use of this retort will help determine the distribution and speciation of $\mathrm{Hg}$, As, Se, and Cd compounds as a function of retorting parameters in shale oil, retort water, and offgas. The first test consisted of heating the $0 i 1$ shale to $500^{\circ} \mathrm{C}$ with a $100 \%$ nitrogen $\left(\mathrm{N}_{2}\right)$ sweep gas. Results of this test demonstrated that the system operates as designed; only two minor modifications were necessary to achieve satisfactory operation of the retort. 



\section{CONTENTS}

INTRODUCTION . . . . . . . . . . . . . 1

PROJECT OBJECTIVES............................. 2

SYSTEMS DESCRIPTION........................... 3

DATA ACQUISITION SYSTEM...................... 5

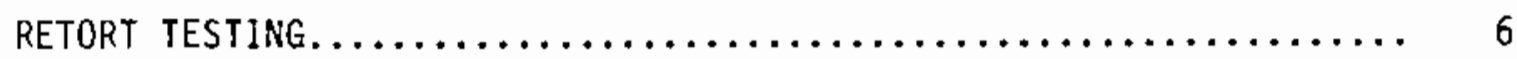

RESULTS AND DISCUSSION OF RETORT RUN PNL $-1 \ldots \ldots \ldots \ldots \ldots \ldots \ldots \ldots . . . \ldots$

ZEEMAN ATOMIC ABSORPTION SYSTEM................... 10

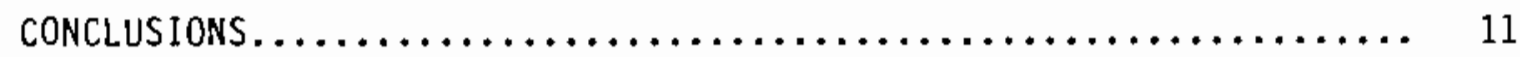

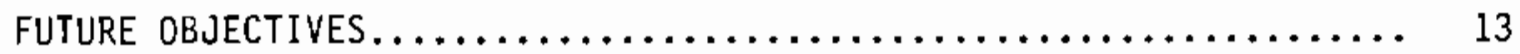

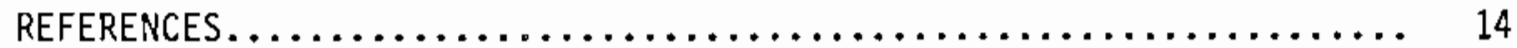


.

. 


\section{INTRODUCTION}

Pacific Northwest Laboratory (PNL) is conducting a program on "Partitioning and Chemical Speciation Studies of Volatile Trace Elements" for the Office of Fossi? Energy of the Department of Energy (DOE). The program goal is to determine the distribution of mercury $(\mathrm{Hg})$, arsenic (As), selenium (Se), and cadmium (Cd) in the offgas, retort water, and shale oil and to determine the chemical species of these elements in the product streams. These elements were chosen because of their likelihood to be volatilized out of the oil shale rock matrix and redistributed into the product streams of a commercial retort. In this study a fully instrumented $6-\mathrm{kg}$ retort $\mathrm{will}^{\mathrm{i}}$ be used to carefully control retorting parameters capable of changing the distribution and species present in the product streams. This information will be helpful in minimizing environmentai concerns while maximizing the quality of the iiquid fuel produced in the retorting process.

This report, the first in a series of three, will describe the construction of the PNL $6-\mathrm{kg}$ retort and the testing and performance of the retorting apparatus. 


\section{PROJECT OBJECTIVES}

The objective of this program is to detemine how retorting process parameters affect the partitioning of $\mathrm{Hg}$, As, Se, and $\mathrm{Cd}$ from raw oil shale to spent shale, shale oil, retort water, and offgas. Because of their volatile nature, a significant fraction of these elements is released from the raw oil shale matrix during retorting and subsequently migrates to the product shale oil, retort water, or offgas streams. Thus, depending on the form(s) of the chemicals in each product stream, these elements may be mobilized into the environment unless removed from the streams before disposal.

For each of the aforementioned elements, the objectives of this study are to 1) determine the distribution coefficients for each product stream; 2) identify the chemical forms in retort water, offgas, and shale oil with particular emphasis on inorganic or organometallic species known or suspected of being carcinogenic or toxic; 3) investigate the mechanism(s) responsible for mobilizing toxic, or labile chemical forms identified in item 2 into each product stream; and 4) determine the effect of retorting rate, maximum retorting temperature, and retorting atmosphere on items 1 and 3 above. 


\section{SYSTEMS DESCRIPTION}

A schematic diagram of the retort system can be seen in Figure 1. The main component of the retorting apparatus is a three-zone Themeraft furnace and its temperature controller unit. The central controlier allows the furnace to be heated at various rates ranging from $0.5^{\circ} \mathrm{C} / \mathrm{min}-$ ute to $10^{\circ} \mathrm{C} /$ minute. The furnace is designed to contain a 10-cm-diameter, 304 stainless-steel retort vessel. A themocouple well is positioned along the centerline of the vessel to monitor the temperature at the top, middle, and bottom of the shale bed.

The sweep gas enters the top of the vessel and flows down through the shale bed. The sweep gas is supplied by compressed gas cylinders and controlled by a pressure regulator and rotometer. The outlet gas temperature is measured by an in-line thermocouple located above the oil/water receiver. The $011 /$ water recejver is maintained at room temperature. From the oil/water receiver, the output gases and condensible vapors are routed to the condensers. Two $0.75-m-10 n g$ glass condensers are connected in series and cooled to $+5^{\circ} \mathrm{C}$ with a refrigerated bath. The offgas temperature is monitored as it exits the condenser system by an in-line thermocouple. On subsequent retort runs, the Zeemane atomic absorption (AA) spectrometer will be used to measure $\mathrm{Hg}$ in the offgas both before and after it passes through the condensers. During the first experiment, retort run $\mathrm{PNL}-1$, a rotometer was used to simulate the offgas flow $(1.0 \mathrm{l} / m i n u t e)$ to the Zeeman AA. This gas was subsequently returned to the system so that the total flow rate of the retort system could be accurateiy determined at a single point.

The retort system is maintained at a positive pressure of 3 psig by a $2.1-m$ retort water column. The retort offgas fiow is monitored by a heat-capacity mass fiowmeter that can be recaibrated during retort runs

- Trademark of Thermcraft, Inc., Winston-Salem, North Carolina.

- Trademark of the HAD Scientific Company, Inc., Berkeley, California. 


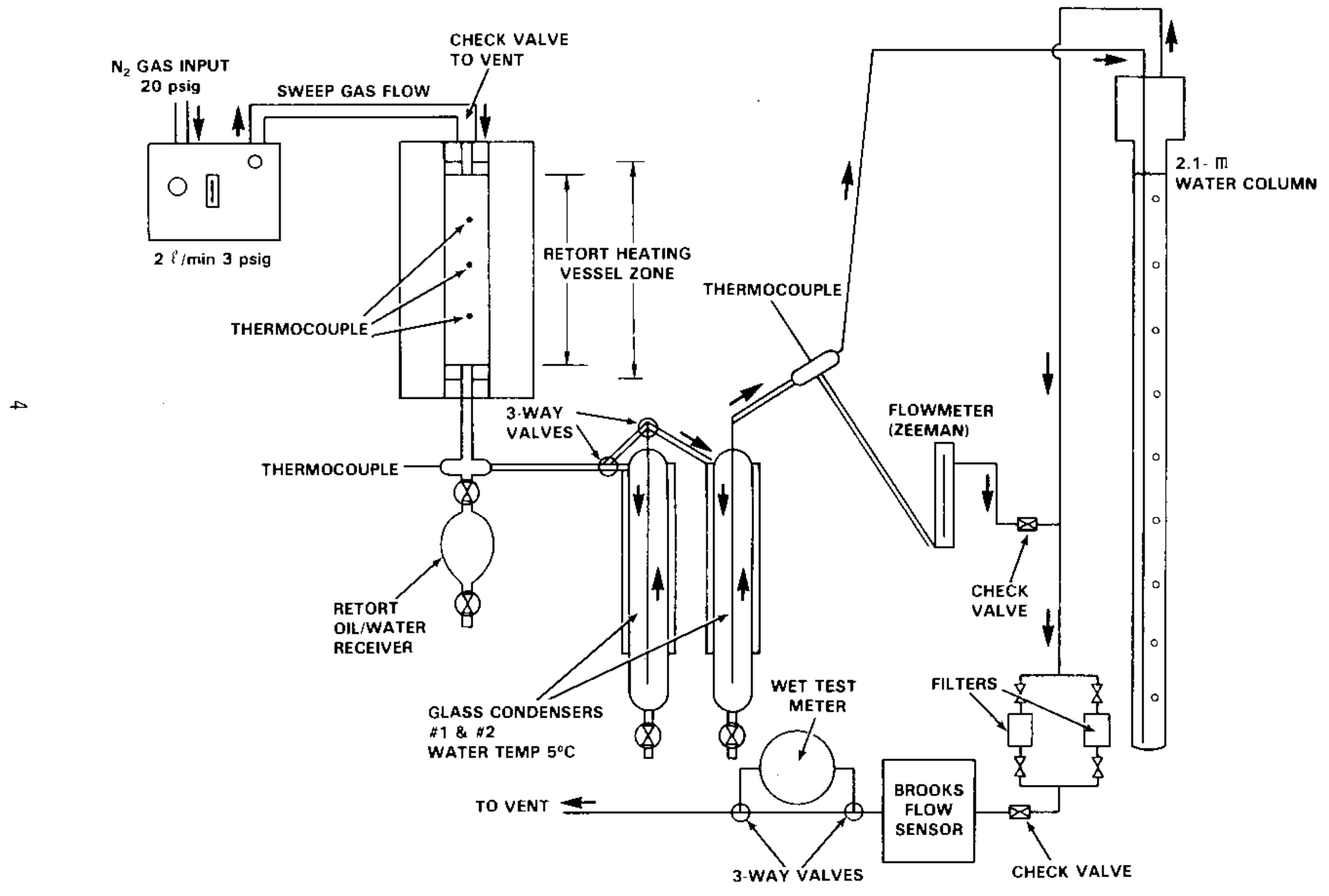

Finure 1. Schemat !o Diagram of PNL 6-kg Retort. 
by periodically passing the offgas through a wet-flow test meter. During retorting, the gas composition changes from $100 \% \mathrm{~N}_{2}$ to a mixed component system containing various amounts of other gases including light hydrocarbons in addition to $\mathrm{N}_{2}$. These additional gases alter the heat capacity of the offgas. This results in a significant error in the readings of the mass flowmeter unless it is recalibrated periodically throughout the run. The thermocouples, mass flowmeter, and wet-test meter are all monitored by the Hewlett-Packard (a) (HP) 3054 data logger system. This system will be discussed below.

DATA ACQUISITION SYSTEM

An HP Model 3D54 data logger is the key component of the retort data acquisition system. This system consists of an HP 3497A data acquisition and control unit and an HP 85A computer. The HP $3497 \mathrm{~A}$ includes two 20-channel analog input cards and a reciprocal frequency counter card. The analog input cards can be connected to thermocouples to record temperatures or can be used simply as voltage recorders for the mass flowmeter or the Zeeman AA output signal. The reciprocal frequency counter is used to monitor interrupts from the wet-test meter for recalibration of the mass flowmeter.

The original version of the data logger software was developed at Lawrence Berkeley Laboratory (LBL), Berkeley, California, and was extensively modified for our application. In its current form, the program can record data for up to 25 channels on a magnetic tape cartridge as well as listing it on the thermal printer concurrently. Five data points are displayed on the screen at selected intervals with the others available to the operator on demand through the use of soft-keys. The program also provides a flow calibration based on wet-test meter datä

(a) Hewlett Packard, Inc., Avondale, Pennsylvania. - Trademark of BBN Research Systems, Cambridge, Massachusetts. 
when the meter is switched into the system. The calibration is displayed on the screen each time a wet-test meter interrupt is received. The mass flowmeter can then be recalibrated to provide an accurate and continuous permanent record on the tape. Final display and reduction of the data will be done on a VAX 11/780 computer system using existing data reduction routines such as the BBN Research Systems RS/l program currently available on the VAX. The data logger program has been modified so that the data written on the tape are in a format that can be transmitted from the retort laboratory to the VAX via telephone lines. A 1200-baud modem, RS-232C interface, and terminal emulator software have been added to the system and fully tested. 


\section{RETORT TESTING}

The two main components of the retorting system that required testing and calibration were the sweep gas system (rotometers and mass flow controllers) and the furnace. Standard reference methods were used to calibrate the wet-test meter, which in turn was used to calibrate the mass flow controllers. The main objectives when calibrating the furnace were 1) to eliminate any temperature differentials between the center zone and the two end zones of the furnace, and 2) to prevent the furnace from overshooting the temperature set point during the heatup phase of the retort run. To satisfy these requirements, the furnace was first tested with an empty retort vessel in place. Three thermocouples were located on the exterior surface of the retort vessel (one near the top and bottom, and one in the center). Next, heating rate tests were conducted with the retort vessel loaded with pea gravel (to simulate a thermal load). The furnace was programmed to heat at $1^{\circ} \mathrm{C} / m i n u t e$ to a maximum temperature of $500^{\circ} \mathrm{C}$. This test run was made with the system monitored by the data acquisition system. A number of minor design modifications were found to be necessary. After these modifications were completed, the retort was prepared for the first actual test run with Anvil Point shale.

The object of retort run PNL-1 was to determine how the retort system would behave under heating rate and gas flow conditions similar to those used in inert gas retort runs at LBL. There, $\mathrm{Hg}$ has been monitored on-line in the offgas and measured in the shale oil and retort waters (Hodgson et a1. 1981). For this run the retort vessel was filled with $6 \mathrm{~kg}$ of raw shale (from $0.25 \mathrm{in}$. to $30(600 \mu \mathrm{m}) \mathrm{mesh}$ ) and suspended in the furnace. An $\mathrm{N}_{2}$ input gas flow rate of $2.0 \mathrm{\ell} / \mathrm{minute}$ and a nominal heating rate of $1.0^{\circ} \mathrm{C} /$ minute $\left(8.2\right.$ hours to reach $\left.500^{\circ} \mathrm{C}\right)$ were selected for retort run PNL-1. The furnace was programmed to level off at $500^{\circ} \mathrm{C}$ and maintain that temperature for 1 hour to bring the retort vessel to $500^{\circ} \mathrm{C}$. When the retort vessel reached $500^{\circ} \mathrm{C}$, the furnace power was turned off and the system allowed to cool to room temperature for 24 hours with $\mathrm{N}_{2}$ flowing through the vessel. 
The data logger monitored the retort temperatures and flow rates at 2-minute intervals. The calibration of the mass flowmeter was checked every 30 minutes during the early part of the run and every 15 minutes during shale oil production $\left(350^{\circ} \mathrm{C}\right.$ to $450^{\circ} \mathrm{C}$ ). At approximately $110^{\circ} \mathrm{C}$, physically adsorbed water on the raw shale was volatilized and condensed from the offgas into the $0 i 1 /$ water receiver vessel and the first condenser. Beginning at about $350^{\circ} \mathrm{C}$, shale oil began to appear in the first condenser. No significant amount of material was collected in the oil/water receiver until near the end of shale oil production. The material that accumulated in the oil/water receiver appeared to be the heavy distillate fraction of the shale oil, which began condensing and congealing immediately after exiting the heated zone of the furnace. 


\section{RESULTS ANO DISCUSSION OF RETORT RUN PNL-1}

Figure 2 contains temperature and flow rate profiles for the 9-hour data acquisition period of retort run PNL-1. The slope of the temperature profile (solid line) was determined using a regression method. The slope, $0.93^{\circ} \mathrm{C} /$ minute, closely matches the $1.0^{\circ} \mathrm{C} /$ minute heating rate set into the temperature programmer. The maximum temperature variation across the furnace during the run was $6^{\circ} \mathrm{C}$ and occurred at the very end of the heating program. Maximum shale oil production occurred at approximately $400^{\circ} \mathrm{C}$, which correlated well with the maximum offgas outlet temperature (dashed line) and offgas flow rate (dotted/dashed line). Shale $0 i 1$ production decreased to zero as the temperature approached $450^{\circ} \mathrm{C}$. Examination of the spent shale revealed clusters of spent shale bound by a reticulated carbon material, which appeared to originate from the residual heavy distillates unable to flow out the retorting zone. The mass balance data for retort run PNL-1 are summarized in Table 1. The weight ratio of spent-to-raw shale was 0.75 . The amount of oil and water recovered was equivalent to 20.4 and $2.16 \mathrm{gal} / \mathrm{ton}$, respectively. These values were $80 \%$ and $65 \%$ of the Fisher Assay results (Table 1), respectively. The values were comparable to those obtained from a series of similar retort runs at LBL (Hodgson et a1. 1981). One notable difference from the LBL retort results was the mass imbalance of $-11 \%$. This appears to have resulted because the mass flowmeter was not recalibrated often enough during the retort run, and possibiy because the molecular weight of the offgas was estimated because no gas composition data were taken. These problems will be remedied in future PNL retort runs.

After two weeks at $4^{\circ} \mathrm{C}$, the shaje oil/retort water mixture was separated into shale $0 i 1$ and retort water fractions. On subsequent retort runs, the shale oil/retort water mixture will be separated immediately after the run. These samples will be analyzed to determine the elemental distribution and speciation for $\mathrm{Hg}$. As, $\mathrm{Se}$, and $\mathrm{Cd}$ in retort product streams. 


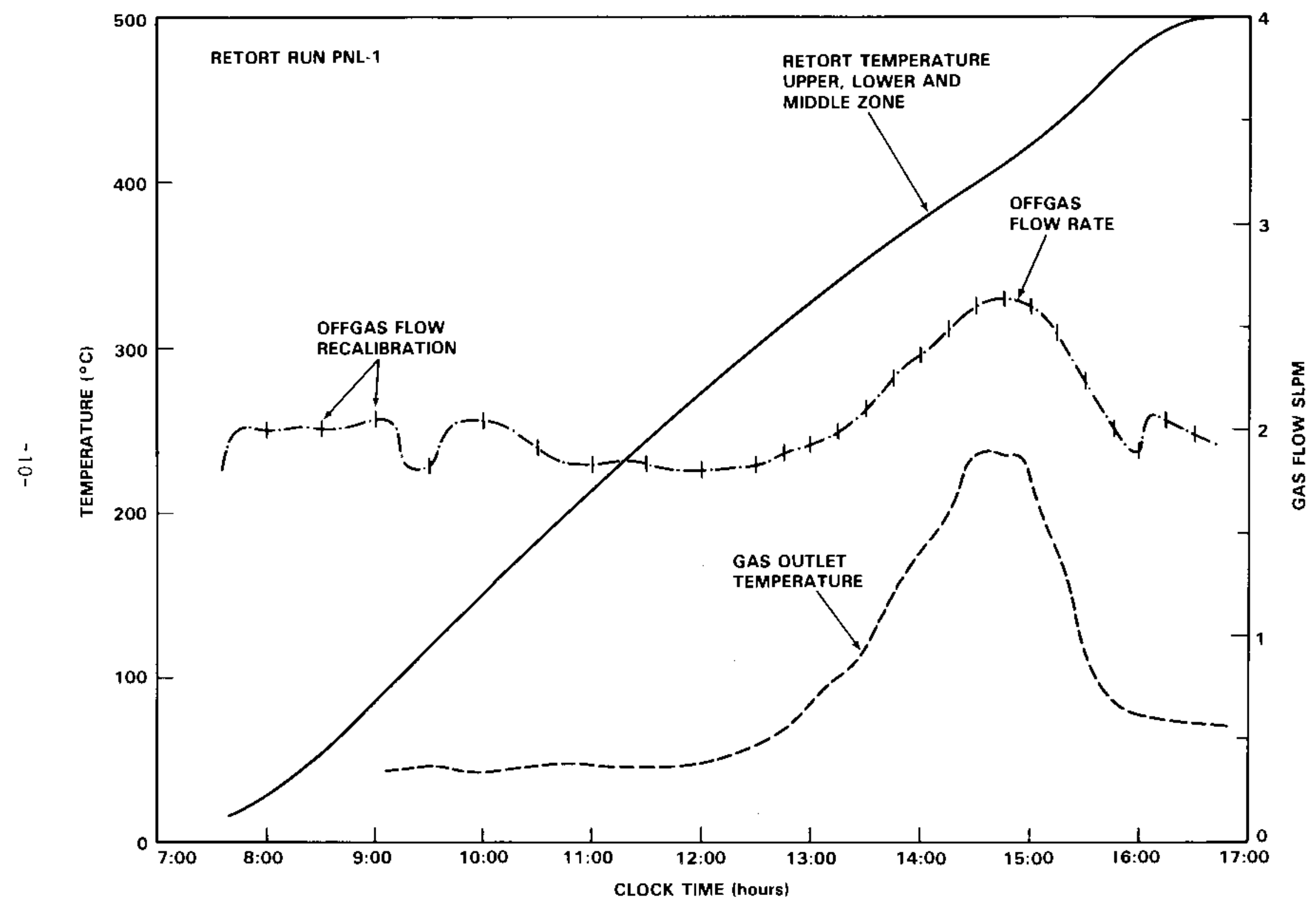

Figure 2. Plot of Retort Temperature, Gas 0utlet Temperature and Gas 0utlet Flow Rate from Retort Run PNL-1. 
TABLE 1

Product Distribution for Laboratory Retort Experiment PNL-1

$\begin{array}{ccc}\text { Material Distribution } & \begin{array}{c}\text { PNL-1 Retort } \\ \text { Mass,gisher Assay } \\ \text { Run, gal/ton }\end{array} & \begin{array}{c}\text { gal/ton } \\ \text { Distribution, } q\end{array}\end{array}$

Raw Shale $\quad 5775.0$

Spent Shale $4308.8 \quad 74.6$

$0 i 1$

447.5

7.7

20.4

25.6

Water

53.9

0.9

2.2

3.4

Gas

5.0

Imbal ance

$-629.9$

$-11.8$

\section{ZEEMAN ATOMIC ABSORPTION SYSTEM}

A Zeeman AA system was obtained from $H A D^{(a)}$ Instruments that was similar to that described by Girvin and Fox (1980). It was delivered in early December 1983 and initial testing performed off-line at that time. It will be used during the second retort run and subsequent $\mathrm{Hg}$ retort runs to monitor the total mercury concentration in the offgas. The HP data logger will be used to collect data from the Zeeman system during the run. Data collected will include both the total uncorrected absorption signal and the net background corrected signai, which are directly proportional to the $\mathrm{Hg}$ concentration present in the offgas.

(a) Hadishi Instruments, Berkeley, California. 


\section{CONCLUSIONS}

The retort operated as expected with two minor exceptions. One difficulty was the distribution of the shale $0 i 1$ and retort water through the plumbing system. This problem was caused because the retort gas was not being cycled through the $0 i 1 /$ water receiver. The original design relied on gravity to direct the flow of condensed retort water and shale oil into the collection vesse1. A redesign of the $0 i 1 /$ water receiver that allows the oil- and water-laden gas stream to impinge on the walls of the container should eliminate this problem. The second problem concerned the efficiency of the condensers, which allowed some minor breakthrough of light distillate. This problem can be easily corrected by the use of an ethylene glycol/water-based coolant. Using this mixture as the heat exchange medium in the refrigeration system witl enable the condensers to be cooled to $-5^{\circ} \mathrm{C}$. This procedure will be tested during the next retort run. This should prevent any significant amount of the light hydrocarbons from accumulating in gas lines or water columns.

The gas handling system, the flow monitor, the data acquisition system and associated software, and the data transmission system from the data logger to the VAX mainframe computer all functioned as designed during retort run PNL-1.

These results have demonstrated that the retorting and data acquisition systems are now fulty operational (see Figure 3 ). 


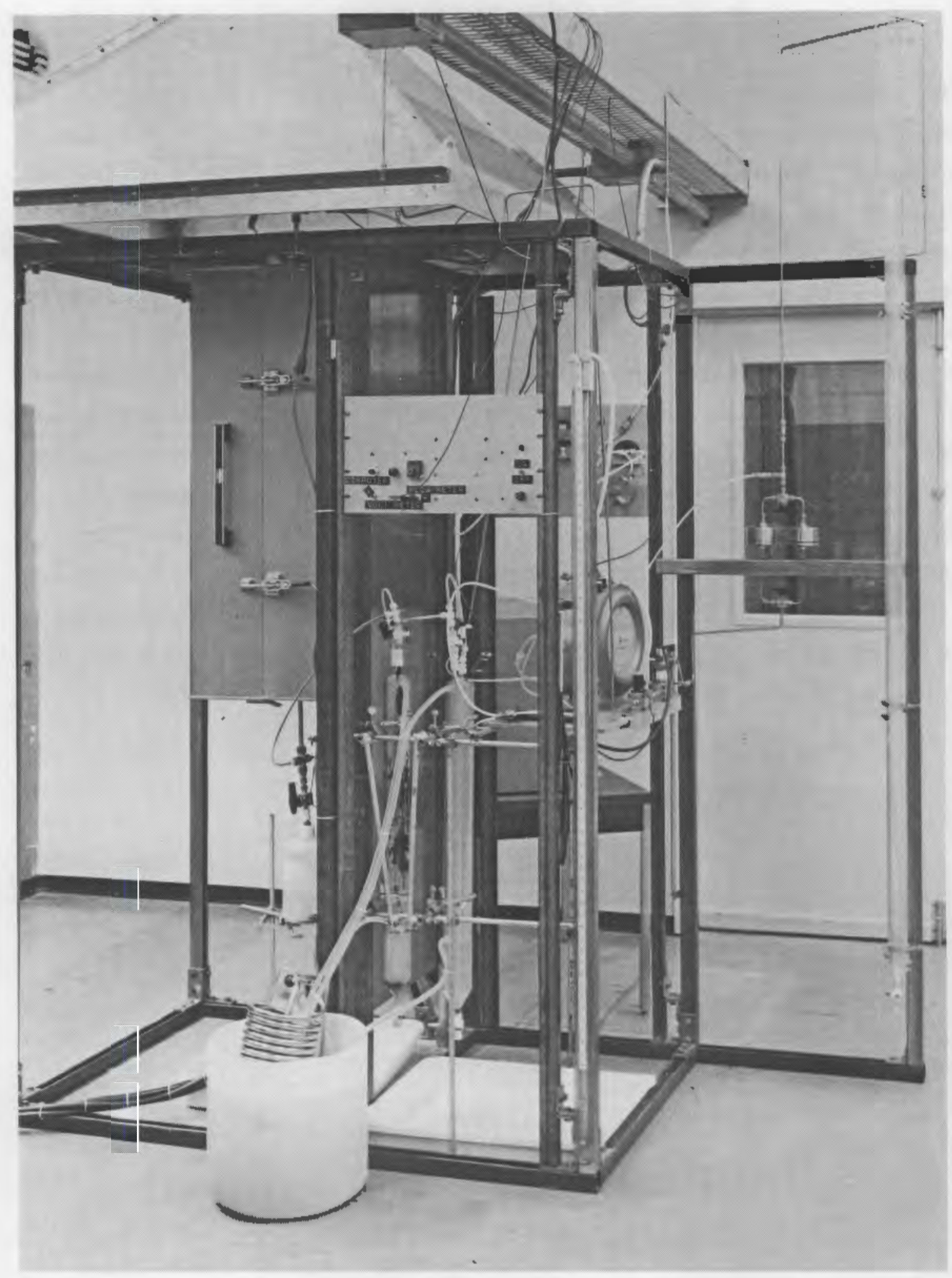

Figure 3. The 6-kg Retort at Pacific Northwest Laboratory. 


\section{FUTURE OBJECTIVES}

The primary administrative objective is to integrate the retorting and analyticai method development programs, previously funded as separate programs. The immediate technical objectives are to conduct retort runs using a gas chromatograph to monitor the offgas composition and the Zeeman AA to measure on-line the total mercury in the offgas. These runs will be followed by subsequent analys is of the shale oil and retort water for total and speciated $\mathrm{Hg}$, As, Se, and Cd. This phase of the program relates to the distribution of material at a maximum temperature of $500^{\circ} \mathrm{C}$. Subsequent retort runs will be run at maximum retorting temperatures of $750^{\circ} \mathrm{C}$ and $1000^{\circ} \mathrm{C}$. Sweep gases that will be used include $100 \% \mathrm{~N}_{2}$ and a mix of $75 \% \mathrm{~N}_{2}$ and $25 \%$ steam. Special emphasis will be placed on simulating the heating rates and sweep gas composition currently used in prominent surface retorting technologies. The product streams from these retort runs will be analyzed and the results compared to determine the relationship between retorting parameters and the distribution of the various chemical forms of $\mathrm{Hg}$, As, Se, and $\mathrm{Cd}$. 


\section{REFERENCES}

Hodgson, A. T., M. J. Pollard, G. J. Harris, D. C. Girvin, J. P. Fox and N. J. Brown. 1981. Mercury Mass Distribution During Laboratory and Simulated In-Situ $0 i 1$ Shale Retorting. LBL-12908, Lawrence Berkeley Laboratory, Berkeley, California.

Girvin, O.C. and J. P. Fox. 1980. On-Line Zeeman Atomic Absorption Spectroscopy for Mercury Analysis in 0il Shale Gases. EPA-600/7-80130, Industrial Environmental Research Laboratory, U.S. Environmenta 1 Protection Agency, Cincinnati, Ohio. 


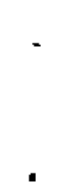

• 
No. of

Copies

OFFSITE

2 T. C. Bartke

Laramie Project Office

U.S. Department of Energy

P.0. Box 1189

Laramie, WY 82070

D. Uthus

Office of Fossil Energy

U.S. Department of Energy

FE-33 GTN

Washington, OC 20545

A. Hartstein

Office of Fossi] Energy

U.S. Department of Energy

FE-33 GTN

Washington, OC 20545

J. W. Ramsey

Office of Fossit Energy

U.S. Department of Energy

FE-34 GTN

Washington, OC 20545

B. J. Davidson

Laramie Project Office Library

U.S. Department of Energy

P.0. Box 1189

Laramie, WY 82070

W. E. Little

Laramie Project Office

U.S. Department of Energy

P.0. Box 1189

Laramie, WY 82070

A. Pitrolo
Morgantown Energy Technology
Center
U.S. Oepartment of Energy
Post Office Box 880
Morgantown, WV 26505
No. of

Copies
C. Rosmiagi
Morgantown Energy Technology Center

U.S. Department of Energy

Post Office Box 880

Morgantown, WV 26505

C. H. Sink

Morgantown Energy Technology Center

U.S. Department of Energy

Post Office Box 880

Morgantown, WV 26505

P. R. Wieber

Morgantown Energy Technology Center

U.S. Department of Energy

Post 0ffice Box 880

Morgantown, WV 26505

27 DOE Technical

Information Center

C. G. Daughton

Lawrence Berkeley Laboratory

I Cyclotron Road

Building 70, Room 128

Berke?ey, CA 94720

A. Lewis

Lawrence Livermore National Laboratories

P.0. Box 808

Livermore, CA 94550

S. R. Skaggs

P.0. Box 1663

MS 5000

Los Alamos Nationa?

Laboratories

Los Alamos, NM 87545 
No. of

Copies

P. J. Hommert

U.S. Department of Energy

Sandia National Laboratory

P.0. Box 5800

Albuquerque, NM 87185

V. Smith

Western Research Institute

P.0. Box 3395

University Station

Laramie, WY 82071

ONSITE

Richland Operations Office

H. E. Ransom

16 Pacific Northwest Laboratory

D. W. Dragnich

J. L. Downs-Berg

J. C. Evans

J. S. Fruchter

D. C. Girvin

P. C. Hays

C. L. Nelson

K. B. Olsen

D. S. Sklarew

R. A. Stokes

Publishing Coordination (2)

Technical Information (5) 